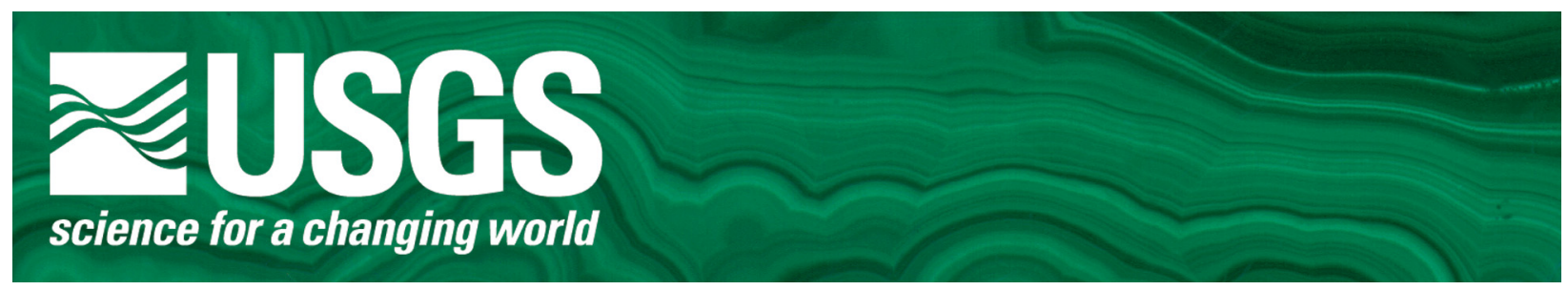

\title{
Mineral Resource Assessment of Selected Areas in Clark and Nye Counties, Nevada-a progress report
}

By Steve Ludington

Any use of trade, firm, or product names is for descriptive purposes only and does not imply endorsement by the U.S. Government

\section{Open-File Report 2004-1339}




\title{
Mineral Resource Assessment of Selected Areas in Clark and Nye Counties, Nevada-a progress report
}

\author{
By Steve Ludington
}

An assessment by the U.S. Geological Survey (USGS) is in progress of known and undiscovered mineral resources of selected areas administered by the Bureau of Land Management (BLM) in Clark and Nye Counties, Nevada. The purpose of this work is to provide the BLM with information for use in their long-term planning process in southern Nevada so that they can make better-informed decisions.

Existing information is being compiled about the areas, including geology, geophysics, geochemistry, and mineral-deposit information, and field examinations of selected areas and mineral occurrences have been conducted to determine their geologic setting and metallogenic characteristics. The work is ongoing.

In February of 2004 USGS and BLM officials met in Las Vegas, Nevada, to determine the appropriate format of reports that would best meet the needs of BLM. It was determined that reports should be in a format similar to BLM's own mineral assessment reports. It was also determined that, in order to meet BLM's needs, all materials must be in their hands by March, 2006.

The assessment is being conducted in partnership with the University of Nevada, Las Vegas (UNLV) and the Nevada Bureau of Mines and Geology (NBMG), a part of the University of Nevada, Reno (UNR). A substantial part of the appropriation for this activity has been provided to these two partners through cooperative agreements with the USGS.

\section{Partners}

Faculty of the geology department at UNLV are supervising a postdoctoral fellow doing research in support of this assessment. His tenure began in September, 2004. UNLV received $\$ 200,000$ of the appropriation; transfer of funds was initiated in March and completed in August of 2004. The theme of the research is the study of the composition and stratigraphy of alluvial fans in Clark County that will help constrain the timing of mineralization and elucidate the geologic history of the area, as well as provide information that will help assess the area for aggregate materials.

Staff of the NBMG are providing expertise in the field of industrial mineral deposits. This contribution fills a scientific need that results from the non-availability of appropriate USGS staff. NBMG received $\$ 100,000$ of the appropriation; transfer of funds was initiated in March and completed in August of 2004. 


\section{Areas being studied}

A total of 25 Areas of Critical Environmental Concern (ACECs) have been identified by BLM as the object of this study. They range from tiny (less than one $\mathrm{km}^{2}$ ) to large (more than $1,000 \mathrm{~km}^{2}$ ). The majority of these areas are not adjacent to or near known mineral deposits, and will require a minimum of extended study and field examination. What follows is a thumbnail description of each area and a preliminary assessment of the research needs for each. The remarks in the summaries below apply only to metallic mineral resources, as the study of industrial mineral deposits, to be conducted primarily by the NBMG and UNLV, has not yet begun. The location of the study areas is shown on Figure 1.

For two of the areas, Hidden Valley and Keyhole Canyon, the assessment of metallic mineral resources has been completed. Draft reports for these areas have been completed and are included here as Appendices A and B.

\section{Piute-Eldorado Valley ACEC}

This is the largest ACEC in the study (about $1,330 \mathrm{~km}^{2}$ ), and the one with the most important unanswered questions about possible mineral deposits. It is receiving the majority of the attention of the study. The area consists primarily of the floors of Piute and Eldorado Valleys, which are both relatively thinly covered with surficial sediments; bedrock is less than 1,000 $\mathrm{m}$ below the surface in most of the area. There are two large excluded areas ("doughnut holes") in the area, one for the northern part of the Highland Range, and one that contains the town of Searchlight and much of the historic Searchlight mining district. An important question is whether extensions of the mineralized system at Searchlight extend beneath a thin veneer of surficial deposits, into the surrounding PiuteEldorado Valley ACEC.

The Searchlight district is unlike most gold deposits in Nevada in two important ways that impact the assessment. First, the rocks and veins have been tilted nearly 90 degrees to the west by post-mineral tectonic events, and thus, this ACEC requires special attention to spatial and structural aspects of the mineralized rocks. Second, the conditions of mineralization appear to have been unusual; alteration minerals are different than at most deposits in the Great Basin. The oxidation state of the system appears to have been quite high, and sulfide minerals, especially normally ubiquitous pyrite, are all but absent.

Studies so far have focused on mapping and sampling of the rocks on the western margin of the Searchlight district, along the boundary of the ACEC and inside the ACEC. More than 80 samples have been collected from this area, and interpretation of their geochemical and petrographic aspects will provide important constraints on interpretation of the concealed extent of the mineralized rocks of the Searchlight district.

A second area of focus in the Piute-Eldorado Valley ACEC is south of the Searchlight district, along the upper margin of the Spirit Mountain pluton, on the southeast margin of the ACEC. This area is similar to the environment of the Searchlight district, in that it lies just above the top of a Miocene-age granitic pluton that could have provided hydrothermal fluids to the wall rocks above. This area is being examined carefully to identify any clues about such possible mineralizing fluids. 


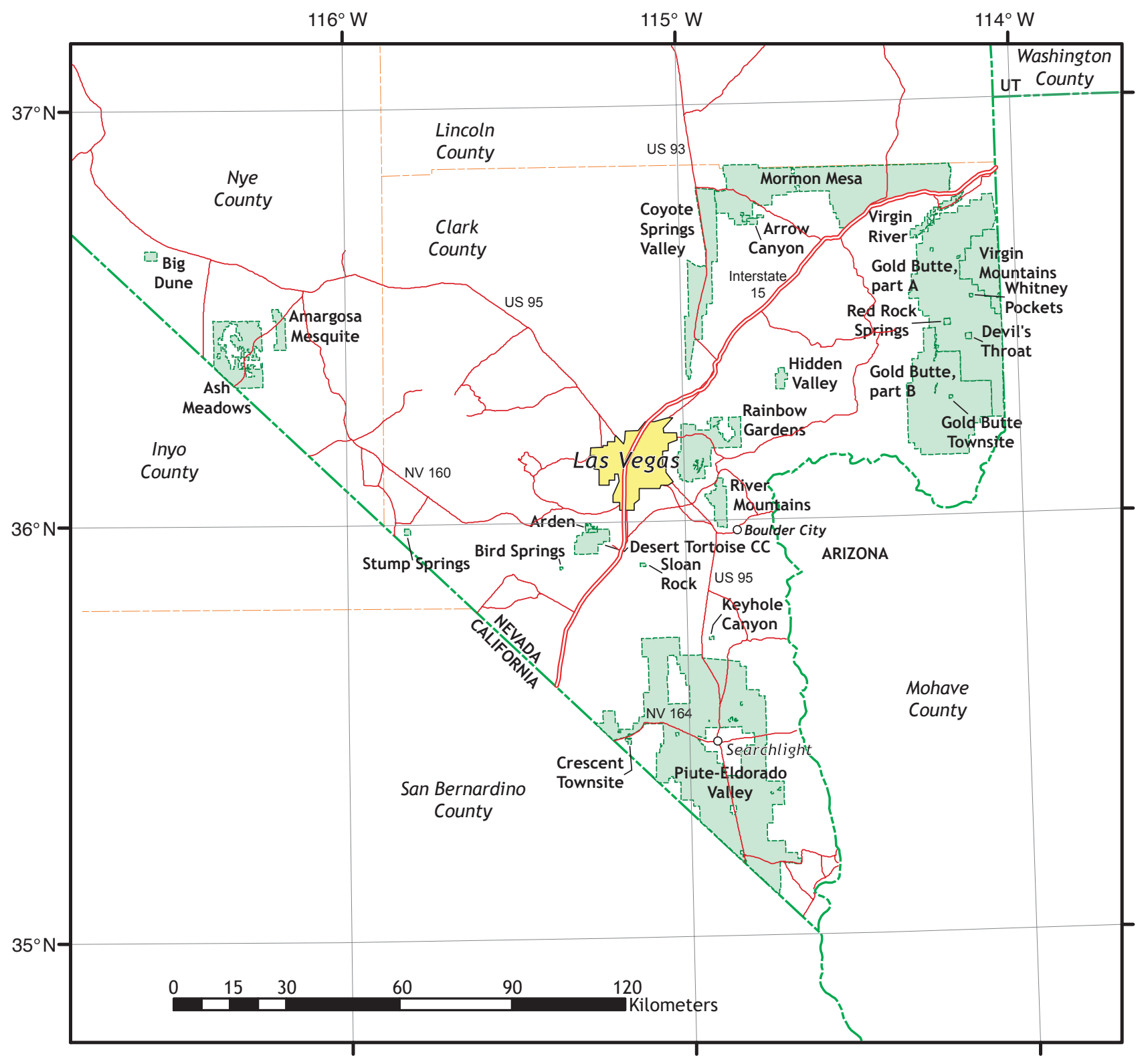

Scale $1: 1,750,000$

Figure 1. Map showing location of study areas (ACECs) in southern Nevada. 


\section{Gold Butte ACEC (parts A and B) and Virgin Mountains ACEC}

These three ACECs are contiguous, and have a combined area about as large as Piute-Eldorado Valleys. Gold Butte, part A is about $750 \mathrm{~km}^{2}$ in area; Gold Butte, part B is about $490 \mathrm{~km}^{2}$; and the Virgin Mountains is about $145 \mathrm{~km}^{2}$. There are three specific types of mineral deposit that require elucidation.

In the north part of the area, in Gold Butte, part A, there are some unique Proterozoic mineral deposits that contain substantial amounts of platinum group elements (PGE). Because they are of uncertain origin, we have initiated studies of these deposits that will help explain their origin, and should allow us to determine whether they might occur more widely in the area.

Near the townsite of Gold Butte, there are a series of copper deposits hosted in Paleozoic carbonate rocks that resemble much larger deposits elsewhere in the world. We will determine if these deposits have characteristics that might suggest the potential for much larger deposits.

In Gold Butte, part B, there are a number of gold-bearing vein deposits about which little is known. These will be visited and examined with the aim of determining their proper classification, which will allow us to provide an assessment of their significance.

\section{Red Rock Springs ACEC, Whitney Pockets ACEC, and Devils Throat ACEC}

These three very small ACECs (each is less than $3 \mathrm{~km}^{2}$ ) are all surrounded by Gold Butte, part A, and are important for archaeological and scenic resources. In the Devils Throat ACEC, a remarkable vertically-walled sinkhole in the alluvium poses a natural hazard. None of the three areas are near any identified mineral deposits, and none appear likely to contain undiscovered resources.

\section{Gold Butte Townsite ACEC}

This very small area (less than $1 \mathrm{~km}^{2}$ ) is important for historic resources and is entirely surrounded by Gold Butte, part B. It is within a few $\mathrm{km}$ of the Gold Butte mine, but has not yet been visited.

\section{Mormon Mesa ACEC, Coyote Springs Valley ACEC, and Arrow Canyon ACEC}

These three areas are contiguous, and are located in the northeast part of Clark County, north of Interstate 15. Mormon Mesa is about $610 \mathrm{~km}^{2}$ in area; Coyote Springs Valley is about $210 \mathrm{~km}^{2}$; and Arrow Canyon is about 8 $\mathrm{km}^{2}$. All these areas are important for desert tortoise habitat, and in addition, Arrow Canyon is important for cultural resources (Miocene bird tracks and prehistoric rock art). The three areas are underlain primarily by Paleozoic limestones, and do not appear likely to contain undiscovered mineral resources, but they will receive some further study. 


\section{Virgin River ACEC}

The Virgin River ACEC is about $30 \mathrm{~km}^{2}$ in area, and is important for riparian habitat (including some threatened or endangered species) and cultural resources. The area is located along the Virgin River, south of Interstate 15 in northeastern Clark County, and exposes primarily recent sedimentary material. There are no important known mineral deposits nearby, and the area seems unlikely to contain important undiscovered mineral resources.

\section{Big Dune ACEC}

The sand dunes in this area of about $8 \mathrm{~km}^{2}$ in Nye County provide a unique biological habitat that supports some rare insects. The area has not yet been visited, and no important mineral deposits are known nearby.

\section{Ash Meadows ACEC and Amargosa Mesquite ACEC}

These two areas in Nye County contain several unique biological habitats that support rare fish, including the Ash Meadows pupfish, and rare bird and plant species. Ash Meadows ACEC is about $150 \mathrm{~km}^{2}$ in area and Amargosa Mesquite ACEC is about $27 \mathrm{~km}^{2}$. Clay has been extracted nearby, but the deposits do not appear to be economically important; the area has not yet been visited.

\section{Rainbow Gardens ACEC}

Rainbow Gardens ACEC is an area of about $160 \mathrm{~km}^{2}$, and is located immediately east of the city of Las Vegas, providing recreation opportunities for the city. The area also contains unique plant habitat, based in part on gypsum-rich rock units. There are no mineral deposits known immediately nearby, though manganese was extracted in the past a few kilometers away.

\section{River Mountains ACEC}

River Mountains ACEC is an area of about $45 \mathrm{~km}^{2}$, on the southeast edge of the Las Vegas urban area, near Boulder City. The area is underlain by Miocene volcanic rocks, and provides an important desert bighorn sheep habitat. There are no important mineral deposits known nearby.

\section{Stump Springs ACEC}

Stump Springs is a small area (less than $3 \mathrm{~km}^{2}$ ), near the California border, west of Las Vegas. It was an important stopover on the Old Spanish Trail between Santa Fe and Los Angeles in the $19^{\text {th }}$ century. There are no important mineral deposits known nearby. 


\section{Arden ACEC}

The Arden ACEC is important for railroad history. It is about $6 \mathrm{~km}^{2}$ in extent. There are no important mineral deposits known nearby, although a large, active limestone quarry lies about $7 \mathrm{~km}$ to the southeast.

\section{Desert Tortoise Conservation Center (CC) ACEC}

The Desert Tortoise Conservation Center adjoins the Arden ACEC on the south, and contains about 45 $\mathrm{km}^{2}$. This area contains important desert tortoise habitat, and also the BLM's tortoise holding facility. The only important mineral deposit known nearby is the large Sloan limestone quarry immediately east of the area.

\section{Bird Springs ACEC}

A small area of less than one $\mathrm{km}^{2}$, Bird Springs ACEC is southwest of Las Vegas, and is important for cultural resources. There are a few inactive limestone quarries nearby, but no important mineral deposits are known.

\section{Sloan Rock ACEC}

A small area of less than $2 \mathrm{~km}^{2}$, this ACEC is underlain by Miocene volcanic rocks and is important for prehistoric rock art. It is within the North McCulloch Wilderness area. There are no important mineral deposits known nearby.

\section{Crescent Townsite ACEC}

The Crescent Townsite ACEC covers less than $2 \mathrm{~km}^{2}$. It is important for its historic buildings that help document the mining history of the area. Several nearby areas have been prospected and explored for metal deposits in the last few decades.

\section{Keyhole Canyon ACEC and Hidden Valley ACEC}

Appendices A and B describe these areas.

\section{Conclusions}

A mineral resource assessment of selected areas in Clark and Nye Counties, Nevada, is underway. Good progress has been made, and, with the help of partners NBMG and UNLV, all assessments are expected to be complete by March of 2006. 


\section{Appendix A. Preliminary Mineral Resource Assessment of the Hidden Valley Area of Critical Environmental Concern, Clark County, Nevada}

\section{Introduction}

This report was prepared for the Bureau of Land Management to provide information for land planning and management, and, specifically, to provide information to aid implementation of the Clark County Conservation of Public Land and Natural Resources Act of 2002 and the Southern Nevada Public Land Management Act of 1998.

The area in question was visited briefly to confirm descriptions of the geology that were gleaned from the scientific literature.

\section{Lands involved}

The Hidden Valley ACEC has an area of about 13.64 sq. km (5.5 sq. mi). It is about $40 \mathrm{~km} \mathrm{NE} \mathrm{of} \mathrm{the} \mathrm{city}$ of Las Vegas. It is reached by secondary roads, and is about $15 \mathrm{~km}$ south of the townsite of Crystal (exit 75 on Interstate 15). The area, like the nearby Valley of Fire State Park, is well known for occurrences of petrified wood and for petroglyphs (rock art) left by prehistoric Native Americans.

\section{Summary, conclusions, and recommendations}

The Hidden Valley ACEC contains occurrences of petrified wood and of petroglyphs. The potential for discovery of deposits of saleable, leasable, or locatable minerals is judged to be low.

\section{Physiographic data}

The Hidden Valley ACEC consists primarily of a flat valley at an elevation of about 1,000 meters, surrounded by hills and mountains that reach elevations of more than 1,600 meters. The area is drained to the north by a tributary of California Wash. Creosote bush, burro bush, and brittle bush are prominent within the desert plant 
community. Birds found in the area include the raven, house finch, sage sparrow, and roadrunner, as well as many migrant birds. Lizards and snakes are common, as well as the coyote, kit fox, spotted skunk, black tailed jack rabbit, and antelope ground squirrel. The desert tortoise, though rare, is known to occur here.

\section{Geologic setting}

The Hidden Valley ACEC is in the central Basin and Range extensional tectonic province, which formed during Tertiary time by tectonic extension, or stretching, of the earth's crust. The province is quite narrow at this latitude, and is bordered on the east by the Colorado Plateau tectonic province, where Proterozoic gneiss and schist are exposed in the Virgin Mountains, less than $40 \mathrm{~km}$ to the east. On the west, unextended Pennsylvanian and Permian limestone and dolomite in the Mojave Desert province are exposed less than $10 \mathrm{~km}$ away.

\section{Site geology}

The valley floor of Hidden Valley and part of its flanks are underlain by Aztec Sandstone, a Jurassic age deposit that is a classic example of an extensive field of sand dunes that has been lithified into rock. The Aztec consists of brick-red to pink, fine- to medium-grained, well-sorted, quartz-rich sandstone. It is characterized by large cross strata considered to be of eolian (wind-blown) origin (Stewart, 1980). It typically weathers to form high cliffs and distinctive knobby outcrops. The Aztec is correlative with the Navajo Sandstone of the Colorado Plateau, and it is the formation that forms distinctive red cliffs at nearby Valley of Fire State Park, at Redrock Canyon in Nevada, and at Zion National Park in Utah.

The hills and valleys surrounding Hidden Valley are made up of Cambrian and Ordovician carbonate rocks. These rocks consist of massive to well-bedded, light- to dark-gray dolomite and limestone that represent a variety of different carbonate marine depositional environments (Longwell and others, 1965; Stewart and Carlson, 1978).

These carbonate rocks were thrust westward over the Aztec Sandstone on the North Buffington back thrust system during the Sevier orogeny, probably in Late Cretaceous time (Carpenter and Carpenter, 1994). This thrust fault system was later deformed and, in places, overturned, in response to the Muddy Mountains thrust system which was formed in earliest Tertiary time, and transported the upper plate rocks to the east (Bohannon, 1983).

No igneous rocks occur in or near the area.

\section{Mining history}

There has been no known mining in the area. Activity within $20 \mathrm{~km}$ of the area has been restricted to smallscale mining of industrial minerals (clay, borates, and gems). 


\section{Mineral Deposits}

The nearest mineral deposits and prospects are: Vanderbilt bedded clay deposit, $10 \mathrm{~km}$ southwest; the Anniversary lacustrine borate deposit, $11 \mathrm{~km}$ south; the Ore Car Mine (gem beryl), $11 \mathrm{~km}$ south; the Bauer-Dollery and Virgin River manganese deposits, $25 \mathrm{~km}$ southeast; the White Basin lacustrine borate deposit, $10 \mathrm{~km}$ east; and the Overton bedded magnesite deposit, $25 \mathrm{~km}$ northeast.

\section{Mineral exploration and development work}

There is no known mineral exploration or development in the ACEC.

In the past, there has been a small amount of petroleum exploration activity in Clark County, particularly in the 1950s and 1980s, and a number of deep wells have been drilled in southern Nevada, but no discoveries of exploitable petroleum have resulted.

\section{Mining, milling, and related operations}

There are no known mining or milling operations.

\section{Sampling procedures and analytical work}

No samples were taken or analyzed.

\section{Mineral potential}

The Hidden Valley ACEC contains no known deposits of locatable minerals. The potential for discovery of same is judged to be low, with a certainty level of C. Definitions of mineral potential and certainty levels are those outlined on p. 7 and 8 of Goudarzi (1984).

\section{References}

Bohannon, R.G., 1983, Mesozoic and Cenozoic tectonic development of the Muddy, North Muddy, and northern Black Mountains, Clark County, Nevada, in Miller, D. M., Todd, V. R., and Howard, K. A., (eds.), Tectonic and stratigraphic studies in the eastern Great Basin, Geological Society of America, Memoir 157, p. 125-148.

Carpenter, D.G. and Carpenter, J.A., 1994, Fold-thrust structure, synorogenic rocks, and structural analysis of the North Muddy and Muddy Mountains, Clark County, Nevada, in Dobbs, S.W. and Taylor, W.J. (eds.), Structural and stratigraphic 
investigations and petroleum potential of Nevada, with special emphasis south of the Railroad Valley producing trend: Nevada Petroleum Society Conference Volume II, p. 65-94.

Goudarzi, G.H., compiler, 1984, Guide to preparation of mineral survey reports on public lands: U.S. Geological Survey Open-file Report 84-0787.

Longwell , C.R., Pampeyan, E.H., Bowyer, Ben, and Roberts, R.J., 1965, Geology and mineral deposits of Clark County, Nevada: Nevada Bureau of Mines, Bulletin 62, $218 \mathrm{p}$.

Stewart, J.H., and Carlson, J.E., 1978, Geologic map of Nevada: U. S. Geological Survey, scale 1:500,000.

Stewart, J.H., 1980, Geology of Nevada-a discussion to accompany the Geologic Map of Nevada, Nevada Bureau of Mines and Geology, Special Publication 4, 136 p. 


\section{Appendix B. Preliminary Mineral Resource Assessment of the Keyhole Canyon Area of Critical Environmental Concern, Clark County, Nevada}

\section{Introduction}

This report was prepared for the Bureau of Land Management to provide information for land planning and management, and, specifically, to provide information to aid implementation of the Clark County Conservation of Public Land and Natural Resources Act of 2002 and the Southern Nevada Public Land Management Act of 1998.

The area in question was visited briefly to confirm descriptions of the geology that were gleaned from the scientific literature.

\section{Lands involved}

The Keyhole Canyon ACEC has an area of about 0.98 sq. km (0.37 sq. mi). It is about $55 \mathrm{~km}$ south of the city of Las Vegas. It is about $4 \mathrm{~km}$ east of U.S. 95, and is reached by a secondary road that leaves U.S. 95 about 30 $\mathrm{km}$ south of the junction with U.S. 93, just west of Boulder City. The area is important for prehistoric Native American rock art.

\section{Summary, conclusions, and recommendations}

The Keyhole Canyon ACEC contains petroglyphs inscribed on Miocene granite. The potential for discovery of locatable minerals is judged to be low.

\section{Physiographic data}

The Keyhole Canyon ACEC consists primarily of alluvial fan, at elevations between 800 and $900 \mathrm{~m}$, at the western foot of the Eldorado Mountains, which rise to an elevation of about 1,300 m immediately to the southeast of 
the area. The area includes the mouth of a usually dry stream that forms steep-walled Keyhole Canyon, cut in granitic rocks at the foot of the range. This stream drains into Eldorado Valley.

\section{Geologic setting}

The Hidden Valley ACEC is in the central Basin and Range extensional tectonic province, which formed during Tertiary time by tectonic extension, or stretching, of the earth's crust. The province is quite narrow at this latitude, and is bordered by the Colorado Plateau tectonic province to the east, and by the Mojave Desert province to the west.

\section{Site geology}

Keyhole Canyon is cut into the extreme northern end of the Keyhole Canyon pluton, a granite body of Miocene age that probably is related to the Nelson Pluton to the east, described by Faulds (1996). This granite intrudes Proterozoic gneiss and schist about $200 \mathrm{~m}$ north of the mouth of the canyon, in the northeast part of the ACEC (Longwell and others, 1965; Stewart and Carlson, 1978).

The granite is distinctly red in color, and consists primarily of quartz, feldspar, and a little biotite. It is massive and strongly resistant to erosion, and forms numerous flat and gently curved near-vertical faces varnished by rock weathering that have provided sites for the abundant prehistorick rock art.

\section{Mining history}

There has been no known mining in the immediate area. However, the Eldorado mining district, near the town of Nelson, is located about $7 \mathrm{~km}$ to the east. Gold was discovered there as early as 1857 (Longwell and others, 1965), and production of gold, silver, copper, lead, and zinc continued on a sporadic basis until the 1950s. Small amounts of gold were produced from the district again in the 1970s. In the early 1990s, an extensive exploration program was conducted in the district that resulted in the delineation of a deposit containing more than 1 million tons of gold ore (Robinson, 1996), but the deposit was never developed.

\section{Mineral Deposits}

The recently-delineated WGB deposit, in the center of the Eldorado district, as described by Robinson (1996), consists of several elliptical, near-surface, subhorizontal pods of disseminated gold. These pods are controlled by a series of subhorizontal shear zones or faults that are the result of extreme extension in the district between about 15 and 10 million years ago. The gold was deposited at very low temperatures (near 100 deg C.) in 
quartz-calcite veins and veinlets that are superimposed on propylitically altered rocks. The deposits exploited in the $19^{\text {th }}$ century and early part of the $20^{\text {th }}$ were vertically-dipping veins that apparently contained the same quartzcalcite-gold mineral assemblage, albeit with some base metals, presumably as sulfide minerals.

Other than the Eldorado district, there are no known mineral deposits within $15 \mathrm{~km}$ of the Keyhole Canyon ACEC.

\section{Mineral exploration and development work}

There is no known mineral exploration or development.

\section{Mining, milling, and related operations}

There are no known mining or milling operations.

\section{Sampling procedures and analytical work}

No samples were taken or analyzed.

\section{Mineral potential}

The Keyhole Canyon ACEC contains no known deposits of locatable minerals. The potential for discovery of same is judged to be low, with a certainty level of C. Definitions of mineral potential and certainty levels are those outlined on p. 7 and 8 of Goudarzi (1984).

\section{References}

Faulds, James E., 1996, Geologic map of the Fire Mountain quadrangle, Nevada and Arizona: Nevada Bureau of Mines and Geology, Map 106, scale 1:24,000.

Goudarzi, G.H., compiler, 1984, Guide to preparation of mineral survey reports on public lands: U.S. Geological Survey Open-file Report 84-0787.

Longwell , C.R., Pampeyan, E.H., Bowyer, Ben, and Roberts, R.J., 1965, Geology and mineral deposits of Clark County, Nevada: Nevada Bureau of Mines and Geology, Bulletin 62, 218 p.

Robinson, J.P., 1996, Structurally-controlled, igneous-hosted, disseminated Au mineralization near Nelson, Nevada, in Coyner, A.R. and Fahey, P.L., eds., Geology and Ore Deposits of the American Cordillera: Geological Society of Nevada Symposium Proceedings, v. I, Reno/Sparks, Nevada, April 1995, p. 567-579.

Stewart, J.H., and Carlson, J.E., 1978, Geologic map of Nevada: U. S. Geological Survey, scale 1:500,000. 